\title{
Regionalism and ECOWAS Trade Performance: A Gravity Model Approach
}

\author{
Afolabi Luqman.O* \\ Universiti Utara Malaysia
}

\author{
Nor Aznin Abu Bakar** \\ Universiti Utara Malaysia
}

Mukhriz Izraf Azman Aziz***

Universiti Utara Malaysia

\begin{abstract}
This paper investigates bilateral trade flows and the level of openness across ECOWAS-15 nations for the period of 1981-2013 using Poisson pseudo maximum likelihood (PPML), fully modified ordinary least squares (FMOLS) and canonical cointegrating regression (CCR). Comparing the results, the ECOWAS dummy variable was negative and significant in all of the estimation techniques. Financial openness under FMOLS and CCR was negatively significant. Trade openness was found to be negatively significant only under PPML. The empirical results indicate that a common border and distance have had a strong effect on ECOWAS trade; also there is a negative effect of trade flow among ECOWAS members. Moreover, the level of financial and trade openness among members impedes the level of trade flows on integration. The estimated results highlight the underlying significance of accurately accounting for endogeneity when estimating trade policy impacts.
\end{abstract}

Keywords: trade flows, ECOWAS, Gravity Model, Panel Data Model, regional trade.

JEL Classifications: F15, C33, F17, F14

\section{Bölgeselcilik ve ECOWAS Ticaret Performansı: Bir Çekim Modeli Uygulaması}

\section{Özet}

Bu çalışmada iki yönlü ticaret ve ticari açıklık ECOWAS üyesi 15 ülkede 1982-2013 zaman aralığı için PPML FMOLS ve CCR yöntemleri kullanarak incelenmektedir. ECOWAS kukla değişkeni tüm tahmin yöntemleri için anlamlı ve negatif olarak tahmin edilmiştir. FMOLS ve CCR yöntemlerinde finansal açıklık da anlamlı ve negatif olarak bulunmuştur. Ticari açıklık ise sadece PPML yöntemiyle anlamlı bir şekilde negatif olarak tesbit edilmiştir. Ampirik bulgular ortak bir sınırın varlığı ile iki ülke arasındaki mesafenin ECOWAS üyesi ülkelerin ticaretine anlamlı etkisi olduğunu göstermiştir. Ayrıca,toplam ticaret, finansal ve ticari açıklığın ise ECOWAS üyesi ülkeler arası ti-

\footnotetext{
* Afolabi Luqman.O is a PhD Research Student in the School of Economics Banking and Finance at Universiti Utara Malaysia, 06010 Sintok Kedah Darul Aman, Malaysia. E-mail: rskjnr001@yahoo.com

** Nor Aznin Abu Bakar is an Associate Professor in the School of Economics Banking and Finance at Universiti Utara Malaysia, 06010 Sintok Kedah Darul Aman, Malaysia. E-mail: noraznin@uum.edu.my

*** Dr Mukhriz Izraf Azman Azizis is an Instructor in the School of Economics Banking and Finance at Universiti Utara Malaysia, 06010 Sintok Kedah Darul Aman, Malaysia. E-mail: mukhriz@uum.edu.my
} 
carete ket vurduğu ortaya çıkmıştır. Ancak, ticaret politikası etkileri değerlendirilirken, içselliğin varlığının da dikkate alınması gerektiği vurgulanmıştır.

Anahtar sözcükler: ticaret akımları, ECOWAS, Çekim Modeli, Panel Veri Modeli, bölgesel ticaret Jel Sinıflamast: F15, C33, F17, F14

$\mathrm{T}$ The impact of a regional trade agreement has generated a lot of debate in economic literature. The rate at which new schemes of commercial integration across the globe appears to be fast accelerating; the enhancements in communications, the decline of transportation costs and the existence of economics of scale have contributed and further strengthened trade globalization. The Economic Community of West African States (ECOWAS) was originated in 1975 by the ECOWAS treaty. Its members consist of Gambia, Ghana, Burkina Faso, Cape Verde, Liberia, Guinea, Senegal, Togo, Nigeria, Niger, Guinea Bissau, Mali, Benin, Cote d'Ivoire and Sierra Leone (ECOWAS 2012). The population of the ECOWAS zone is around 300 million, with a GDP of approximately 316 billion dollars; the region represented about $4.5 \%$ of the world population, but added only $0.5 \%$ to the global GDP. Studies on ECOWAS regional integration are subtle, hence the few available ones either discover a positive effect or no effect of ECOWAS regional integration. The mixed empirical findings might be due to some factors such as the countries selected or the period chosen for the study.

However, the gravity model of international trade has been widely used and acceptable in predicting trade flows between countries, groups and regions for the past fifty years. Criticism and intense debate surrounding the theoretical underpinning for the gravity model estimation, both in the eighties and nineties, led to a sound theoretical background for gravity models. A multiplicative and linearised gravity model was estimated using Ordinary Least Squares (OLS) techniques, supposing that the variance of the error was found to be constant across the observations (i.e., homoscedasticity or employing panel techniques assumed that the error is constant across all country-pairs).

According to Silva and Tenreyro (2006), in the presence of heteroscedasticity, the Pseudo Poisson Maximum Likelihood (PPML) performs better than Ordinary Least Squares (OLS). Other challenges facing OLS is the issues of zero values omission and endogeneity. Helpman et al. (2008) proposed a theoretical approach for these zero values with the introduction of a model that uses heterogeneity of firms.

Some researchers adapted PPML to predict the trade flow. Lately, Siliverstov and Schumacher (2007), Martinez-Zarzoso et al. (2007), Westerlund and Wilhelmsson (2007), Martin and Pham (2008), and Burger et al. (2009) obtained differing results when comparing the result with the alternative estimators that deal with zero values and heteroscedasticity problems.

Thus, the objectives of this article is twofold. Our aforementioned objective is to contribute to the methodological discussion by comparing various estimation techniques. The second objective is to check the general effect of ECOWAS regional integration agreements on trade flows among its members, and also to determine the level of openness using a panel cointegration approach to estimate the gravity model of bilateral trade flows within 15 ECOWAS countries. 
The outline of this article is as follows: Section 2 presents a review of the existing literature on the gravity model. Section 3 focuses on the methodological approach, including data sources that were employed in this article. A discussion of the results, concentrating mainly on the trade impact of ECOWAS integration and the level of openness, is presented in Sections four. Section 5 presents a conclusion.

\section{Literature Review}

A gravity model was introduced to study trade flows under international trade by Tinbergen (1962) and Poyhonen (1963). Initially, the gravity model did not have a theoretical basis until the 1970s. This led to various improvements and discussions of a theoretical basis for a gravity equation. A -microeconomics theory formed the basis for gravity models including trade theories and the new economic geography. Virtually most of all these theories gave a detailed explanation for the existence of various types of trade/ views which gave birth to the design of similar gravity models. Similarly, a theoretically grounded approach for gravity models to reconnoiter trade flow at international level was greatly developed by Hanson and Xiang (2002), Anderson (1979), Evenett and Keller (1998), Bergstrand (1989, 1990) and Anderson and van Wincoop (2003).

In this framework, Deardorff (1998) indicated that the gravity model is well-matched with a varied range of business models, and Heckscher-Ohlin trade was hampered without or with friction. Theoretical contributions studies led Cheng and Wall (1999) to indicate that the gravity model has changed from a mortification of poverty to a theoretically grounded approach which has also yielded to the mortification of wealth.

Furthermore, Laser and Schrader (2002) proved that distances can be measured in two ways: virtual and real geographical distances. It is imperative for empirical studies to acknowledge the significance of distance under the trade relation of nations. The speedy reduction in the costs of communication and information has not caused the demise of distance (Ghemawat 2001). Numerous gravity models have been extensively used to estimate the effect of diversity of political matters, including regional trade, monetary unions, historical ties and political blocs (Soloaga and Winters 2001; Freund 1998; Djankov and Freund 2002). Natural trading partners can emerge based on their comparative advantages, tastes, technology, infrastructure, habits, and similar historical settings.

Numerous researchers have discovered the gains from regional trade practices. Viners (1950) for the first time discovered the two contradictory consequences of each nation's RTA participation Generally a country will benefit more when trading with another participant with lesser cost after import tariffs are reduced or entirely removed. The result of trade creation is a fast-tracking free trade area via improving resource distribution within the zone.

Trade diversion amounted to beefing up protection from resources beyond the area. The long run result depends on which one is bigger, i.e. trade diversion or trade creation; a trade creation effect will lead to welfare improvement while trade diversion might lead to welfare loss. If most of the country around the globe engage in welfare improvement, 
there might be a global welfare improvement, otherwise many countries might experience welfare loss which might damage the global welfare status. However, many researchers have discovered that trade diversion does not exist. For example Yeast (1998), Crawford and Laird (2001) noticed that trade diversion in MERCOSUR (Common Market of the South Americans) was caused due to lesser imports from non-members and afterward it changed the import style of the countries that were involved in importing.

\section{Methodology and Data}

The new trade theory was developed by Helpman and Krugman (1985). This theory serves as the basis for a return to factor proportion principles. It is also regarded to as the Heckscher- Ohlin model (Heckscher 1919; Ohlin 1933). Generally, this theory provides an in-depth explanation for patterns of trade in relation to relative factor abundance. Explicitly, countries with abundant capital that specialize in producing goods on an absolute advantage tend to export goods that are capital intensive in nature, and then import labor for intensive products.

Furthermore, Linder (1961) proposed a demand-based theory which was used to explain the similarity in terms of trade demand features among trading partners. Aggregating goods preference by importing goods from country $i$ is related to the patterns of consumption in exporting country $\mathrm{j}$. Thus, country $\mathrm{i}$ tends to develop industries related to country j's demand. The exchange of particular goods among countries will greatly depend on production at a continuous level, and demand for related and differentiated goods. Combining demand and supply of trade theories within the Heckscher-Ohlin and Chamberlin Linder frameworks, GDP and GDP per capita were identified based on their separate roles by Bergstrand (1989).

Moreover, Gruber and Vernon (1970) improved Linder's hypothesis by adding the differences of per capita incomes among two or more countries in absolute terms into the gravity equation in order to capture the likely consumption pattern differences: If a negative coefficient is discovered, it shows that the trade of both countries is positively related, and also that the pattern of consumption and per capita incomes are linked. This is in line with the Linder hypothesis. Any positive coefficient supports proportions under the theory of trade.

Helpman and Krugman (1985), using the data of trade among industrialized nations, discovered that industrialized nations can be characterized better by their similarities than by their factor endowments differences. Helpman (1987) postulates the share of intra-industry trade that serves as the total value of partners involved in trade as a proxy to determine the relative country size and factor endowments. In summary, Equation (1) adapts the cross-section specification using panel settings indicated by Helpman (1987).

The specification of a triple index for the gravity model was proposed by Matyas (1997) in order to serve as the control variables represented by a dummy. This effect is country-specific for countries under export, as well as the importing country, and also 
shows the common shocks that can likely occur affecting all the countries in the region. Some factors were highlighted by Hummels and Levinsohn (1995) as either unique among countries or which might also vary depending on the countries involved. It includes: cultural ties, border trade, trade restrictions of individual countries and seasonal trade, all of which can be incorporated into the gravity model as country specific pair effects. Combining all the particular effects into one was tested in a model by Egger and Pfaffermayr (2003).

However, despite the tremendous increase of studies on the panel unit root testing and cointegration, gravity model the variables were largely ignored. For the purpose of this study, the methods of Im et al. (2003) and Pedroni are used to check whether the variables are non-stationary, and also to test further whether they are cointegrated. Several approaches can be used to estimate the long-run relationship among the variables.

Another issue that arises when it comes to estimation under the gravity equation is the issue of log or log impasse. It is assumed that log-linearization of the error term tends to change the property of the error term. Consequently, this leads to inefficient estimations due to heteroscedasticity. The assumption is that if data are homoscedastic in nature, the variance of the error term should remain constant, and the anticipated value must be constant as well. If data are heteroscedastic, as it used to be with regard to trade data, then the anticipated value of the error term is a function of the regressors. OLS is not efficient since the conditional distribution of dependent variables is altered.

This point was highlighted several times by Silva and Tenreyro (2006, 2007 and 2008). The critical point was that "the log linearization of the empirical model in the presence of heteroscedasticity leads to inconsistent estimates due to the fact the expected value of the logarithm of a random variable largely depends on higher-order moments of its distribution" (Silva and Tenreyro, 2006)The main sources of heteroscedasticity in data are not unique. The variance of error term may differ with the regressors as well as with the dependent variables or omitted Variables.

Kalirajan (2008) indicated that Anderson's (1979) theoretical model included what is referred to as economic distance between countries. In practice, the concept is always replaced by geographical distance.

Silva and Tenreyro (2006) pointed out that a variance of an error term is always correlated with other countries' GDP, and with the measure of distance. However, another solution suggested by Silva and Tenreyro was to model estimates in levels, and not with logarithms. Based on this suggestion, OLS problems can be avoided. They further suggested two alternative techniques, Poisson Pseudo Maximum Likelihood (PPML) and Nonlinear Least Squares (NLS). Finally, PPML was chosen as the most efficient. The main reason why NLS was not efficient was because it gives more weight to noisier observations, thus reducing the estimator efficiency.

In order to specify the gravity model in a cross-sectional manner, PPML, FMOLS, and CCR specifications are explicitly comprised of time-invariant variables. Thus, the specification of the gravity model of bilateral export can be stated as follows: 
$E_{X P O R T}^{t}=\alpha_{1}+\alpha_{2}$ TOTALGDP $_{i j}^{t}+\alpha_{3} \operatorname{SIMGDP}_{i j}^{t}+\alpha_{4} \operatorname{DIFFGDGPPC}_{i j}^{t}+\alpha_{5}$ ECOWAS $_{i j}^{t}+$ $\alpha_{6}$ Trade Openness $_{i j}^{t}+\alpha_{7}$ Financial Openness $_{i j}^{t}+U_{i j}^{t}$.........

Where represents the export flows within 15 ECOWAS partner countries, using US dollars at constant 2000 prices. Also, the ECOWAS dummy is denoted by 1 when both countries become members of ECOWAS, otherwise it is zero. This variable captures the trade effect of the ECOWAS treaty accession of 1993. The similarity index can be calculated by the size of each country pair using the following formula:

$$
: S I M G D P_{i j}^{t}=\log \left\{1-\left[G D P_{i}^{t} /\left(G D P_{i}^{t}+G D P_{j}^{t}\right)\right]^{2}+\left[G D P_{j}^{t} /\left(G D P_{i}^{t}+G D P_{j}^{t}\right)\right]^{2}\right.
$$

Relative factor endowments can be captured with GDP per capita by taking the absolute difference that are also in log form, which are given as:

$$
D I F F G D G P P C_{i j}^{t}=\left(\ln G D P P C_{i}^{t}-\ln G D P P C_{j}^{t}\right)
$$

The total GDP is the addition of both countries' GDP taken into log form, which can be written as:

$$
\text { TOTALGDP } P_{i j}^{t}=\left(G D P_{i}^{t}+G D P_{j}^{t}\right)
$$

In order to incorporate the other components of the gravity model in this study, the theory specified variables must be included, which were formulated as:

$$
\begin{aligned}
& \text { EXPORT }_{i j}^{t}=\alpha_{1}+\alpha_{2} \text { TOTALGDP } P_{i j}^{t}+\alpha_{3} \operatorname{SIMGDP}_{i j}^{t}+\alpha_{4} \text { DIFFGDGPPC } C_{i j}^{t}+\alpha_{5} \text { DISTANCE }_{i j}^{t}+ \\
& \alpha_{6} L A N G U A G E_{i j}^{t}+ \\
& \alpha_{7} \text { ECOWAS }_{i j}^{t}+\alpha_{8} \text { Trade Openness }{ }_{i j}^{t}+\alpha_{9} \text { Financial Openness } s_{i j}^{t}+\alpha_{10} \text { Coting }_{i j}^{t}+ \\
& U_{i j}^{t}
\end{aligned}
$$

The trade openness variable can be measured by import plus export divided by GDP; this gives an index to measure the level of a country's openness to trade. Financial openness was constructed mainly from binary dummy variables that were used to categorize the tabulation of restrictions on cross-border financial transactions. The results were stated in the IMF's Annual Report on Exchange Arrangements and Exchange Restrictions .

The DISTANCE $E_{i j}^{t}$ variable was measured using kilometers between the capital cities of all exporting countries under ECOWAS. $L A N G U A G E_{i j}^{t}$ represents the historical linkage 
and cultural background between all partners (ECOWAS). Contig represents the sharing of the border within ECOWAS; logarithms were taken for all non-dummy variables.

The countries represented are Gambia, Ghana, Burkina Faso, Cape Verde, Liberia, Guinea, Senegal, Togo, Nigeria ,Niger, Guinea Bissau, Mali, Benin, Cote d'Ivoire and Sierra Leone, for the period of 1983 -2013. Bilateral exports of the 15 countries were used for panel estimation with observation of 6510 (15 x $14 \times 31)$.

Data were sourced from the following sources: (1) flow of export for ECOWAS countries (denominated in US Dollars), which was downloaded from the International Monetary Fund (2014), specifically under the Direction of Trade Statistics; this was determined using US producer prices of $2000=100$; (2) per capita GDP and GDP variables were sourced from the World Bank Indicators Database reported in US dollars; and (3) time-invariant variables including distance and language were downloaded from CEPII.

\section{Empirical Analysis}

Based on panel unit root and panel cointegration testing, the gravity model variables were tested using panel unit root in order to determine the stationarity level before estimating the model. The panel unit root includes different types; panel unit root testing differs from the time series approach due to the stationarity or non-stationarity property of the null hypothesis. Panel variants primarily depend on data that is balanced or unbalanced and on whether cross-sectional dependence and heterogeneity are allowed or not.

However, the panel data used for these study is unbalanced due to missing datas especially from countries like Sierra Leone, Liberia, Guinea Bissau and Mali. Export, GDP per capita and GDP were incomplete; thus, applying second generation panel test tests to unbalanced panel data can create computational problems such as the Westerlund error-correction-based panel cointegration tests.

Furthermore, we could not employ cross sectional dependency test and others; thus we stick to the first generation panel unit root testing and cointegration which was in line with Hondroyiannis (2006) and Geldi (2012). In summary, regardless of whether there is cross sectional dependency or otherwise, we rely on the assumption of Phillips and Moon (1999) that there is independence in the errors across cross-sections using dynamic models. We consider various forms of the residual-based panel Fully Modified OLS (FMOLS) and Canonical cointegrating Regression CCR (Phillips and Moon, 1999; Pedroni, 2000, 2001; Kao and Chiang, 2000; Mark and Sul, 2003) that produce asymptotically unbiased, normally distributed coefficient estimates.

Table 1 shows the unit root test conducted using the Hadri (2000) theory. The results show that all variables are integrated at the first difference I (1). 
Table 1

Panel Unit Root Result

\begin{tabular}{l|c|c|c|c}
\hline \multirow{2}{*}{ Regressors } & Hadri & $\begin{array}{c}\text { Level } \\
\text { Heteroscedastic } \\
\text { ConsistentZ-stat }\end{array}$ & HadriZ-stat & $\begin{array}{c}\text { First differences } \\
\text { Heteroscedastic } \\
\text { ConsistentZ-stat }\end{array}$ \\
\hline \multirow{2}{*}{ Total GDP } & $27.7648^{* * *}$ & $27.7648^{* * *}$ & -0.09597 & 0.09597 \\
& $(0.0000)$ & $(0.0000)$ & $(0.5382)$ & $(0.5382)$ \\
\hline \multirow{2}{*}{ GDP Similarity } & $6.13174^{* * *}$ & $6.13174^{* * *}$ & -0.24701 & -0.24701 \\
& $(0.0000)$ & $(0.0000)$ & $(0.5976)$ & $(0.5976)$ \\
\hline \multirow{2}{*}{ GDPPC } & $28.1941^{* * *}$ & $28.1941^{* * *}$ & 0.20509 & 0.20509 \\
& $(0.0000)$ & $(0.0000)$ & $(0.4188)$ & $(0.4188)$ \\
\hline \multirow{2}{*}{ Exports } & $12.0414^{* * *}$ & $12.0414^{* * *}$ & -5.39092 & -5.39092 \\
& $(0.0000)$ & $(0.0000)$ & $(1.0000)$ & $(1.0000)$ \\
\hline \multirow{2}{*}{ Kopen } & $37.8137 * * *$ & $37.8137^{* * *}$ & -3.63637 & -3.63637 \\
& $(0.0000)$ & $(0.0000)$ & $(0.9999)$ & $(0.9999)$ \\
\hline \multirow{2}{*}{ Topen } & $25.9105^{* * *}$ & $25.9105^{* * *}$ & 1.83483 & 1.83483 \\
& $(0.0000)$ & $(0.0000)$ & $(0.4333)$ & $(0.4333)$ \\
\hline
\end{tabular}

The cointegration test using Pedroni's (1999) model is presented in Table 2. The panel statistics are augmented Dickey-Fuller ADF (1979) t-statistics. The variance ratio test represented by panel v and panel P is called Phillips and Perron's (1988) ratio. The cointegration test that is based on group statistics permits the presence of heterogeneity mainly on the coefficients in the long run. It can also accommodate both individual trends and intercepts into the equation.

Table 2

Pedroni Panel Cointegration Test Results

\begin{tabular}{l|c|c|c|c|c|c|c}
\hline Equation & $\begin{array}{c}\text { Panel } \\
\mathbf{v}\end{array}$ & $\begin{array}{c}\text { Panel } \\
\text { rho }\end{array}$ & $\begin{array}{c}\text { Panel } \\
\text { PP }\end{array}$ & $\begin{array}{c}\text { Panel } \\
\text { ADF }\end{array}$ & $\begin{array}{c}\text { Group } \\
\text { rho }\end{array}$ & $\begin{array}{c}\text { Group } \\
\text { PP }\end{array}$ & $\begin{array}{c}\text { Group } \\
\text { ADF }\end{array}$ \\
\hline ECOWAS1a & $13.82^{* * *}$ & 8.66 & $-79.85^{* * *}$ & $-42.45^{* * *}$ & 15.07 & $-91.92^{* * *}$ & $-46.94^{* * *}$ \\
\hline ECOWAS1b & $4.84^{* * *}$ & 13.11 & $-80.90^{* * *}$ & $-39.35^{* * *}$ & 18.84 & $-87.56^{* * *}$ & $-40.63^{* * *}$ \\
\hline
\end{tabular}

Note: The test was conducted using residuals from the panel cointegrating regression, null hypothesis test of no cointegration against the alternative that all series are stationary (Pedroni 1999). ECOWASla permits heterogeneous intercepts; ECOWASIb permits individual trends that have linear and intercepts. One lag length was specified as the maximum chosen by Schwarz info criteria. Significance levels $(* * *, * *)$ are at $1 \%$ and $5 \%$ respectively.

Table 3 presents the estimated result for the gravity model of ECOWAS determinants. The FMOLS and CCR estimators of cointegrating vectors take control of likely endogeneity occurring from the joint determination of exports and other variables. Concerning the parameters estimators, as shown in Table 3, the coefficient signs were in accord with theoretical predictions.

Total GDP and GDP similarity indexes are significant; the positive and significant signs of the coefficient Total GDP and GDP similarity indicate that relative and economic 
size is a paramount tool for trade. Many of the countries that are similar economically have close and important trade relations. The level of significance attributed to the GDP similarity measured the development gap. The coefficient of the total GDP and GDP similarity index is relatively small. A compariosn among PPML, FMOLS and CCR shows the importance of controlling the heterogeneity bias. Considering the income per head variable, the positive and significant coefficient recorded by all the estimates demonstrates that the development gaps between countries considered for estimates are the main factors affecting the flow of exports. The income per head variable supports the Linder hypothesis that the similarity of demand characteristics among ECOWAS nations will increase the trade. In literature, it can be interpreted in terms of factor endowments.

Table 3

Gravity Model of Export

\begin{tabular}{|c|c|c|c|c|}
\hline Regressors & FMOLS & PPML & & CCR \\
\hline Total GDP & $15.460 * * *(7.73)$ & $.136^{* * *}$ & (28.93) & $14.860 * * *(7.30)$ \\
\hline GDP Similarity & $.755 * * * \quad(3.38)$ & $.061 * * *$ & (12.67) & $.672 * * * \quad(2.95)$ \\
\hline GDPPC & $1.030^{* * *} \quad(4.88)$ & $.070^{* * *}$ & (16.19) & $1.111^{* * *} \quad(5.38)$ \\
\hline Distance & $-.502 * * \quad(2.13)$ & $-.024 * * *$ & $(-7.68)$ & $-.436^{*}$ \\
\hline Language & $(1.14)$ & $.027^{* * *}$ & $(4.05)$ & $(0.36)$ \\
\hline ECOWAS & $-.898 * * \quad(-2.32)$ &.$-.024 * * *$ & $(-2.94)$ & $-.661^{*}$ \\
\hline Topen & $(0.56)$ & $-.016^{* * *}$ & $(-4.83)$ & $(1.01)$ \\
\hline Fopen & $-.479^{*} \quad(-1.67)$ & -.0050 & $(-1.56)$ & $(-1.88)$ \\
\hline $\begin{array}{l}\text { Contig } \\
\text { RMSE }\end{array}$ & $\begin{array}{ll}.996^{* *} & (2.47) \\
3.067 & \end{array}$ & $.066^{* * *}$ & $(9.60)$ & $\begin{array}{l}1.078^{* * *}(2.61) \\
3.240\end{array}$ \\
\hline
\end{tabular}

Note: "Heteroskedasticity robustness are reported in parentheses using test statistics (White 1980). FMOLS and CCR are estimated using I(1) explanatory variables that are cointegrated and generated from a regression that involves two pre-and post-future values using first differences. Coefficients estimated under the first stage are substituted into equation (I), while the remaining parameters of the model are estimated (Bun and Klaassen 2007). Also, PPML results reported in parentheses undergo semi robustness, which is in line with Santos Silva and Tenreyro (2010). Significance is indicated by *, **, ***at $10 \%, 5 \%$ and $1 \%$ respectively.

Distance has a negative effect on the volume of trade between the 15 nations (ECOWAS). In other words, the greater the distance between ECOWAS countries, the less they engage in trade. This result is in line with the classical gravity model results. An increase in the distance between countries $\mathrm{i}$ to $\mathrm{j}$ by $1 \%$ will lead to a decrease in export that can be on average $-0.24 \%$. The decrease is constant for all the estimates. The trade openness variable is negative and significant only under PPML, while for the remaining it was not significant. The implication of this negative trend means that the flow of goods within ECOWAS is hampered by the failure of some countries to embrace full liberalization in order to spur growth in the long run. 
It is worthy to note the financial openness of the countries within ECOWAS; the index was negative and significant at $10 \%$ in two out of the three estimates that were used. Countries' financial openness tends to hamper the flow of goods within ECOWAS, and in the long run, it does not favor nor promote the pro-liberal/free trade policies adopted by ECOWAS trade.

Furthermore, contig represents sharing the same border among countries within ECOWAS. The higher significant level accorded to the variable (at 1\%) indicates that countries sharing the border within ECOWAS tend to trade more, which eventually increases the bilateral trade relation.

Moreover, sharing an officially common language is positive and statistically significant: the similar language tends to increasingly stimulate trade among them (Kahouli and Maktouf 2013). It is imperative to discuss and analyze the impact of regional grouping using the coefficient of Intra-ECOWAS variable which was negative and significant in all the three estimates. There is export diversion, and the finding seems logical considering the small volume of trade within the members of the countries; at the same time most of the countries' specialization and production were almost identical.

\section{Conclusion}

Using the panel cointegration method in estimating the gravity model of international trade also safeguards us against the problem of spurious regression. The difference in the results indicated that a critical feature of gravity modeling is heterogeneity.

However, based on the increasing number of Regional Trade Agreements (RTAs) over the years and especially starting from the mid-1990s, both the trade flows and their effects have received considerable attention.

The unexpected negative impact on trade under RTAs among member countries can be demonstrated using dummy variables within the framework of the gravity model. The gravity model became well-known mainly because of the success achieved empirically including its simplicity and flexibility in explaining trade patterns. This article examined the impact of ECOWAS trade flow, and also investigated the level of openness to trade among members within the period of 1983-2013.

The spread of regional trade has generated much criticism over the years. One of the criticisms in some quarters is the fear of a trade diversion caused by advancing an effective non-member country toward a member status that would be less efficient, particularly in terms of production. Within the study area, there is an untapped potential for export to some partners within member states.

Based on the empirical results, ECOWAS member countries should move toward better regional integration in order to increase trade flows and promote economic growth.

Moreover, looking at the level of openness both financially and in welcoming other trading partners, it is clear that some of the countries within ECOWAS have not embraced the liberalization policies fully. Consequently, restrictive polices need to be removed in order to improve trade performance within ECOWAS.

However, the result indicated that policy makers need to develop and encourage a trade flow that will boost economic development. Empirical results may help regional 
governing bodies of ECOWAS to identify the structural differences and react to market needs. It is imperative for ECOWAS to develop and encourage members to remove all restrictive policies that hinder trade in order to achieve better performance.

Another way ECOWAS performance can be improved is the development of a robust policy on an industrial production base in order to improve the capacity of competitiveness of all members. Finally, it is imperative that ECOWAS move to another level of regional integration in order to enhance their overall performance.

\section{References}

Aitken, N.D. (1973). "The Effect of the EEC and EFTA on European Trade: A Temporal Cross-section Analysis," The American Economic Review, 63(5): 881-892.

Anderson, J.E. and van Wincoop, E. (2003). "Gravity with Gravitas: A Solution to the Border Puzzle," American Economic Review, 93(1): 170.

Bagwell, K. and Staiger, R.W. (1998). "Will Preferential Agreements Undermine the Multilateral Trading System?” The Economic Journal, 108(449): 1162-1182.

Baldwin, R. (1993). A Domino Theory of Regionalism. National Bureau of Economic Research.

Bergstrand, J.H. (1985). "The Gravity Equation in International Trade: Some Microeconomic Foundations and Empirical Evidence," The Review of Economics and Statistics, 67(3): 474-481.

, (1989). "The Generalized Gravity Equation, Monopolistic Competition, and the Factor-Proportions Theory in International Trade," The Review of Economics and Statistics, 71(1): 143-153.

Bhagwati, J. (1993). "Regionalism and Multilateralism: An Overview," in J. de Melo and A. Panagariya (eds.), New Dimensions Regional Integration: 22-51. New York: Cambridge University Press.

Bun, M.J. and, Klaassen, F.J. (2007). "The Euro Effect on Trade is not as Large as Commonly Thought," Oxford Bulletin of Economics and Statistics, 69(4): 473-496.

Burger, M.J., Frank, G. Oort, and Linders, G.J.M. (2009). " "On the Specification of the Gravity Model of Trade: Zeros, Excess Zeros and Zero-Inflated Estimation," Forthcoming in Spatial Economic Analysis. Working paper version: ERIM Research Report 2009-003-ORG.

Cooper, C.A. and Massell, B.F. (1965). "A New Look at Customs Union Theory,” The Economic Journal, 71: 742-747.

Dam, K.W. (1963). "Regional Economic Arrangements and the GATT: The Legacy of a Misconception," The University of Chicago Law Review, 30(4): 615-665.

Deardorff, A. (1998). "Determinants of Bilateral Trade: Does Gravity Work in a Neoclassical World?" The Regionalization of the World Economy: 7-32, University of Chicago Press.

ECOWAS. (2012). "ECOWAS Working with Partners to Improve Business Climate in West Africa," Retrieved 10/2/2015, 2015. Available [online at]: http://news.ecowas.int/presseshow. php?nb=317\&lang=en\&annee $=2012$

Egger, P. and Pfaffermayr, M. (2004). "Distance, Trade and FDI: A Hausman-Taylor SUR Qpproach," Journal of Applied Econometrics, 19(2): 227-246.

Evenett, S.J. and Keller, W. (1998). On Theories Explaining the Success of the Gravity Equation. National Bureau of Economic Research. 
Geldi, H.K. (2012). "Trade Effects of Regional Integration: A Panel Cointegration Analysis," Economic Modelling, 29(5): 1566-1570.

Grossman, G.M. and Helpman, E. (1993). The Politics of Free Trade Agreements. National Bureau of Economic Research.

Gruber, W.H. and Vernon, R. (1970). "The Technology Factor," in R.Vernon (ed.) A World Trade Matrix The Technology Factor in International Trade: 233-302. New York: NBER.

Heckscher, E.F. and Ohlin, B.G. (1991). Heckscher-Ohlin Trade Theory. The MIT Press.

Helpman, E. (1987). "Imperfect Competition and International Trade: Evidence from Fourteen Industrial Countries," Journal of the Japanese and International Economies, 1(1): 62-81.

Helpman, E. and Krugman, P.R. (1985). Market Structure and Foreign Trade: Increasing Returns, Imperfect Competition, and the International Economy. MIT Press.

Helpman, E., Melitz, M., and Rubinstein, Y. (2007). Estimating Trade Flows: Trading Partners and Trading Volumes. National Bureau of Economic Research.

Henderson, D. and Millimet, D. (2008). “Is Gravity Linear?” Journal of Applied Economics, 23: 137-172

Hondroyiannis, G. (2006). "Private Saving Determinants in European Countries: A Panel Cointegration Approach,” The Social Science Journal, 43(4): 553-569.

Hummels, D. and Levinsohn, J. (1993). Monopolistic Competition and International Trade: Reconsidering the Evidence. National Bureau of Economic Research.

Im, K.S., Pesaran, M.H., and Shin, Y. (2003). "Testing for Unit Roots in Heterogeneous Panels," Journal of Econometrics, 115(1): 53-74.

Kahouli, B. and Maktouf, S. (2015). "Trade Creation and Diversion Effects in the Mediterranean Area: Econometric Analysis by Gravity Model," The Journal of International Trade and Economic Development, 24(1): 76-104.

Kao, C. and Chiang, M.H. (2000). "On the Estimation and Inference of a Cointegrated Regression in Panel Data," in B.H. Baltagi et al. (eds.), Nonstationary Panels, Panel Cointegration and Dynamic Panels: 179-222.

Kavallari, A., Maas, S., and Schmitz, P.M. (2008). "Explaining German Imports of Olive Oil: Evidence from A Gravity Model," European Association of Agricultural Economists; International Congress, August 26-29, 2008, Ghent, Belgium 44217.

Krishna, P. (1998). "Regionalism and Multilateralism: A Political Economy Approach," Quarterly Journal of Economics, 113(1): 27-251.

Levy, P.I. (1997). "A Political-economic Analysis of Free-trade Agreements," The American Economic Review, 87(4): 506-519.

Linder, S.B. (1961). An Essay on Trade and Transformation. Wiley.

Linnemann, H. (1966). An Econometric Study of International Trade Flows (Vol. 234). North-Holland Publishing Company, Amsterdam.

Lipsey, R.G. (1960). "The Theory of Customs Unions: A General Survey,” The Economic Journal, 496-513.

Mátyás, L. (1997). "Proper Econometric Specification of the Gravity Model," The World Economy, 20(3): 363-368. 
Mark, N.C. and Sul, D. (2003). "Cointegration Vector Estimation by Panel DOLS and Long-run Money Demand," Oxford Bulletin of Economics and Statistics, 65(5): 655-680.

Martin, W. and Pham. C.S. (2008). "Estimating the Gravity Equation when Zero Trade Flows are Frequent," MPRA Paper No. 9453

Martínez-Zarzoso, I., Nowak-Lehmann, D.F., and Vollmer, S. (2007). "The Log of Gravity Revisited," Center for European, Governance and Economic Development Research. Discussion Papers 64.

Narayan, P.K. and Smyth, R. (2008). "Energy Consumption and Real GDP in G7 Countries: New Evidence from Panel Cointegration with Structural Breaks," Energy Economics, 30(5): 2331-2341.

Nelson C.M. and Sul, D. (2003). "Cointegration Vector Estimation by Panel DOLS and Long-run Money Demand," Oxford Bulletin of Economics and Statistics, 65(5): 655-680.

Pedroni, P. (1999). "Critical Values for Cointegration Tests in Heterogeneous Panels with Multiple Regressors," Oxford Bulletin of Economics and Statistics, 61(S1): 653-670.

(2000). "Fully Modified OLS for Heterogeneous Cointegrated Panels," in B.H. Baltagi et al. (eds.), Nonstationary Panels, Panel Cointegration and Dynamic Panels: 93-130. Amsterdam: Elsevier

......, (2001). "Purchasing Power Parity Tests in Cointegrated Panels," The Review of Economics and Statistics, MIT Press, 83(4): 727-731.

Phillips, P.C. and Perron, P. (1988). "Testing for a Unit Root in Time Series Regression," Biometrika," 75(2): 335-346.

Phillips, P.C.B. and Moon, H.R. (1999). "Linear Regression Limit Theory for Nonstationary Panel Data," Econometrica, 67(5): 1057-1111.

Pöyhönen, P. (1963). “A Tentative Model for the Volume of Trade between Countries," Weltwirtschaftliches Archiv, 90: 93-100.

Sapir, A. (2001). "Domino Effects in Western European Regional Trade 1960-1992," European Journal of Political Economy, 17(2): 377-388.

Serlenga, L. and Shin, Y. (2007). "Gravity Models of Intra-EU Trade: Application of the CCEP-HT Estimation in Heterogeneous Panels with Unobserved Common Time-specific Factors," Journal of Applied Economics, 22: 361-381

Silva, J.M.C.S. and Silvana Tenreyro, T. (2006). "The Log of Gravity," Review of Economics and Statistics, 88(4): 641-658.

....., (2008). "Trading Partners and Trading Volume: Implementing the Helpman-MelitzRubinsteinModel Empirically,” University of Essex, Discussion Paper Series 662.

Tinbergen, J. (1962). Shaping the World Economy; Suggestions for an International Economic Policy. New York. Twentieth Century Fund.

White, H. (1980). A Heteroskedasticity-consistent Covariance Matrix Estimator and a Direct Test for Heteroskedasticity," Econometrica: Journal of the Econometric Society, 48(4): 817-838.

Westerlund, J. and Wilhelmsson, F. (2006). "Estimating the Gravity Model without Gravity using Panel Data," Nationale Konomiska Institutionen Department of Economics, WP

W.T.O. (2015). "Regional Trade Agreements," Retrieved 10/2/2015, from wto http://www.wto.org/ english/tratop_e/region_e/region_e.htm 